DOI: $10.35757 / R P N .2010 .18 .14$

\title{
Angelika Ebbinghaus (Hrsg.), Die letzte Chance? 1968 in Ost- europa. Analysen und Berichte über ein Schlüsseljahr
}

VSA-Verlag, Hamburg 2008, ss. 257.

1968 rok był pełen drastycznych wydarzeń, politycznych nadziei i rozczarowań. Był to kluczowy rok nie tylko dla Europy Zachodniej, ale także dla Europy Wschodniej. Wydarzenia 1968 roku miały charakter ruchu protestacyjnego w wielu krajach, zwłaszcza w Stanach Zjednoczonych, RFN, Francji, Czechosłowacji, Polsce i na Węgrzech. W recenzowanej książce została podjęta próba porównania cech wspólnych oraz różnic rewolty 1968 roku we wszystkich krajach bloku wschodniego, jak również w obydwu częściach Europy.

W krajach zachodnioeuropejskich, jak Francja, RFN, Włochy, młodzież, studenci buntowali się przeciwko kapitalizmowi, elitom, powojennemu społeczeństwu i ich wartościom. Głównym punktem ich odniesienia była wojna $\mathrm{w}$ Wietnamie. Natomiast w Europie Wschodniej ludzie zaczęli odrzucać stalinizm, krytykować polityczne prześladowania i represje po 1945 roku, a przede wszystkim pragnęli efektywniejszego państwowego planu gospodarczego i politycznej wolności. Efektem były protesty społeczne młodych ludzi, przede wszystkim studentów. W książce wielokrotnie podkreślano, że w Europie Wschodniej rok ten był przede wszystkim związany z politycznymi i gospodarczymi próbami reform w Czechosłowacji. Reformy oraz wydarzenia w tym państwie stanowiły główny punkt odniesienia dla krajów bloku wschodniego. Wojskowe stłumienie eksperymentów reform miały ogromne oddziaływanie polityczne, sięgające daleko poza Czechosłowacką Republikę 
Socjalistyczną. W centrum zainteresowania niniejszej książki znajdują się głównie wydarzenia Praskiej Wiosny, wraz z jej stłumieniem, oraz polskie wydarzenia marcowe. Militarna interwencja wojsk Układu Warszawskiego w Czechosłowacji zniszczyła we wszystkich krajach Europy Wschodniej nadzieję na wolnościowy i egalitarny socjalizm. Jest to temat przewodni recenzowanej książki. Dyskutowano w niej także o tym, jak wydarzenia te oddziaływały na zachodni ruch 1968 roku. Ponadto wielokrotnie roważano i podejmowano próbę odpowiedzi na pytanie, jak dalece ruch 1968 roku na Wschodzie i Zachodzie wzajemnie oddziaływał i wpływał na siebie.

Redaktorem książki jest Angelika Ebbinghaus - historyk i psychoterapeutka, przewodnicząca fundacji Historii Społecznej XX wieku oraz wieloletnia współwydawczyni czasopisma „1999. Zeitschrift für Sozialgeschichte des 20. und 21. Jahrhunderts"/,,Sozial Geschichte. Zeitschrift für historische Analyse des 20. und 21. Jahrhunderts". Zorganizowała ona wraz z Fundacją Historii Społecznej XX wieku i dzięki wsparciu finansowemu Fundacji im. Róży Luxemburg konferencję na temat: „Rok 1968 z perspektywy społeczeństw Wschodniej, Środkowej i Południowo-Wschodniej Europy". Konferencja odbyła się w lutym 2008 roku w Bremie. Pokłosiem konferencji jest recenzowana książka.

Autorami tekstów są wybitni fachowcy, którzy zajmują się wydarzeniami 1968 roku. Naukowcy z Niemiec, Rosji, Czech, Polski, Węgier i Bułgarii wnieśli swój wkład w nowe spojrzenie na kluczowe zagadnienia roku 1968. W książce znajdują się interesujące i ciekawe dokumenty oraz fotografie, które rozszerzają spojrzenie na wydarzenia 1968 roku i zarazem uzupełniają analizy i relacje w niej zawarte.

Warto sięgnąć po niniejszą publikację, ponieważ stanowi ciekawy zarys wydarzeń 1968 roku głównie w Europie Wschodniej. Książkę powinien przeczytać każdy, kto interesuje się protestami społecznymi w PRL i innych krajach bloku wschodniego, a zarazem w całej Europie i Stanach Zjednoczonych oraz ten, kto chciałby poszerzyć wiedzę o tych czasach i wydarzeniach. 